\title{
Tectonic evolution and deep to shallow geometry of Nagamachi-Rifu Active Fault System, NE Japan
}

\author{
Hiroshi Sato ${ }^{1}$, Toshifumi Imaizumi ${ }^{2}$, Takeyoshi Yoshida ${ }^{3}$, Hisao Ito $^{4}$, and Akira Hasegawa ${ }^{5}$ \\ ${ }^{1}$ Earthquake Research Institute, the University of Tokyo, Tokyo 113-0032, Japan \\ ${ }^{2}$ Department of Geography, Yamanashi University, Kofu 400-8510, Japan \\ ${ }^{3}$ Institute of Mineralogy, Petrology and Economic Geology, Graduate School of Science, Tohoku University, Sendai 980-8578, Japan \\ ${ }^{4}$ National Institute of Advanced Industrial Science and Technology, Tsukuba 305-8576, Japan \\ ${ }^{5}$ Research Center for Prediction of Earthquakes and Volcanic Eruption, Graduate School of Science, Tohoku University, Sendai 980-8578, Japan
}

(Received January 24, 2002; Revised July 15, 2002; Accepted July 29, 2002)

\begin{abstract}
The Nagamachi-Rifu fault is an active reverse fault which trends NE-SW across the central part of Sendai City for over $21 \mathrm{~km}$ distance. The fault does not emerge at the surface and, accompanied with the Dainenji-yama fault, shows wedge thrusting in the Tertiary sediments. The amount of net slip of the master part of the Nagamachi-Rifu fault is estimated to be one $\mathrm{mm} /$ year. Seismic reflection profiles across the fault plus a gravity anomaly reveal the thicker Neogene sediments on the hanging wall rather than on the footwall. The Neogene sedimentary basin was formed by normal faulting in early Miocene under an extensional stress regime associated with the formation of the northern Honshu rift system. Due to shortening deformation since the Pliocene, this Miocene normal fault reactivated as a reverse fault. Judging from the CMP deep seismic reflection profile and location of the 1998 M5.0 Sendai earthquake, the deep geometry of the Nagamachi-Rifu fault is listric.
\end{abstract}

\section{Introduction}

The Nagamachi-Rifu fault is an active reverse fault which runs in the NE-SW direction across the central part of Sendai City over a distance of $21 \mathrm{~km}$. This fault is assessed by the local prefectural government with a potential to produce a destructive earthquake of magnitude 7 (Miyagi Prefectural Government, 1997). A multi-disciplinary investigation to detect the on-going slip along the deeper extension of the Nagamachi-Rifu fault was started in 1998 (Hasegawa et al., 2001). To reveal the aseismic slip along the deeper extension of an active fault, the deep fault-geometry as well as monitoring of crustal movements are important keys. Also, the geometry of the source fault plays an important role for estimating the strong ground motion associated with a scenario earthquake. This paper provides the geologic information to estimate the deep fault-geometry of the Nagamachi-Rifu active fault system and explores the tectonic evolution of this fault system.

\section{Geologic Setting}

The geologic structure of Sendai and its adjacent area is largely affected by three Neogene tectonic events (Sato, 1994), such as extensional deformation in the early Miocene, formation of calderas in late Miocene and final shortening deformation since late Pliocene (Fig. 1). The formation of early Miocene half grabens started ca. $17 \mathrm{Ma}$. The Miocene half grabens were mapped by mainly surface geology and gravity anomaly data (Kitamura et al., 1986; Kitamura,

Copy right(c) The Society of Geomagnetism and Earth, Planetary and Space Sciences (SGEPSS); The Seismological Society of Japan; The Volcanological Society of Japan; The Geodetic Society of Japan; The Japanese Society for Planetary Sciences.
1986; Nakamura, 1992; Amano, 1980; Hiroshima et al., 1991). The early half grabens were controlled by normal faults trending NNW to NW and were followed by younger grabens trending NE-SW. After the middle Miocene subsidence associated with the formation of the northern Honshu rift system, the Ou Backbone Range was gently uplifted. From $7 \mathrm{Ma}$ to $2 \mathrm{Ma}$ a large number of calderas were formed in the western part of Sendai and Ou Backbone Range (Yoshida, 2001). They are mainly collapsed calderas, $10 \mathrm{~km}$ in diameter, that erupted felsic volcanics on land. Since the late Pliocene, due to regional compressional stress trending WNW-ESE, Miocene normal faults were reactivated as reverse faults. The style of volcanism also changed to andesitic strato-volcanoes in the Quaternary.

\section{Active Tectonic Features of the Nagamachi-Rifu Fault}

Based on the late Quaternary geomorphologic features, the Nagamachi-Rifu fault is traced NE-SW for $21 \mathrm{~km}$ distance across the central part of the Sendai City (Fig. 2). The Nagamachi-Rifu fault forms a fault system, including the Dainenji-yama fault and Nigatake blind fault. The Nigatake blind fault is identified based on a topographic flexure, which separates the gentle slope of the uplifted alluvial surface in the hanging wall to the flat alluvial surface in the footwall (Imaizumi et al., 2002). This flexure is also detected by the seismic reflection profile shown in Fig. 3 as growth strata of latest Pliocene to Quaternary sediments. Based on the deformation of river terraces on the hanging wall, the vertical slip rate of the Nagamachi-Rifu fault was estimated to be more than $0.5 \mathrm{~mm} /$ year (Nakata et al., 1976; Otsuki et al., 1977). 

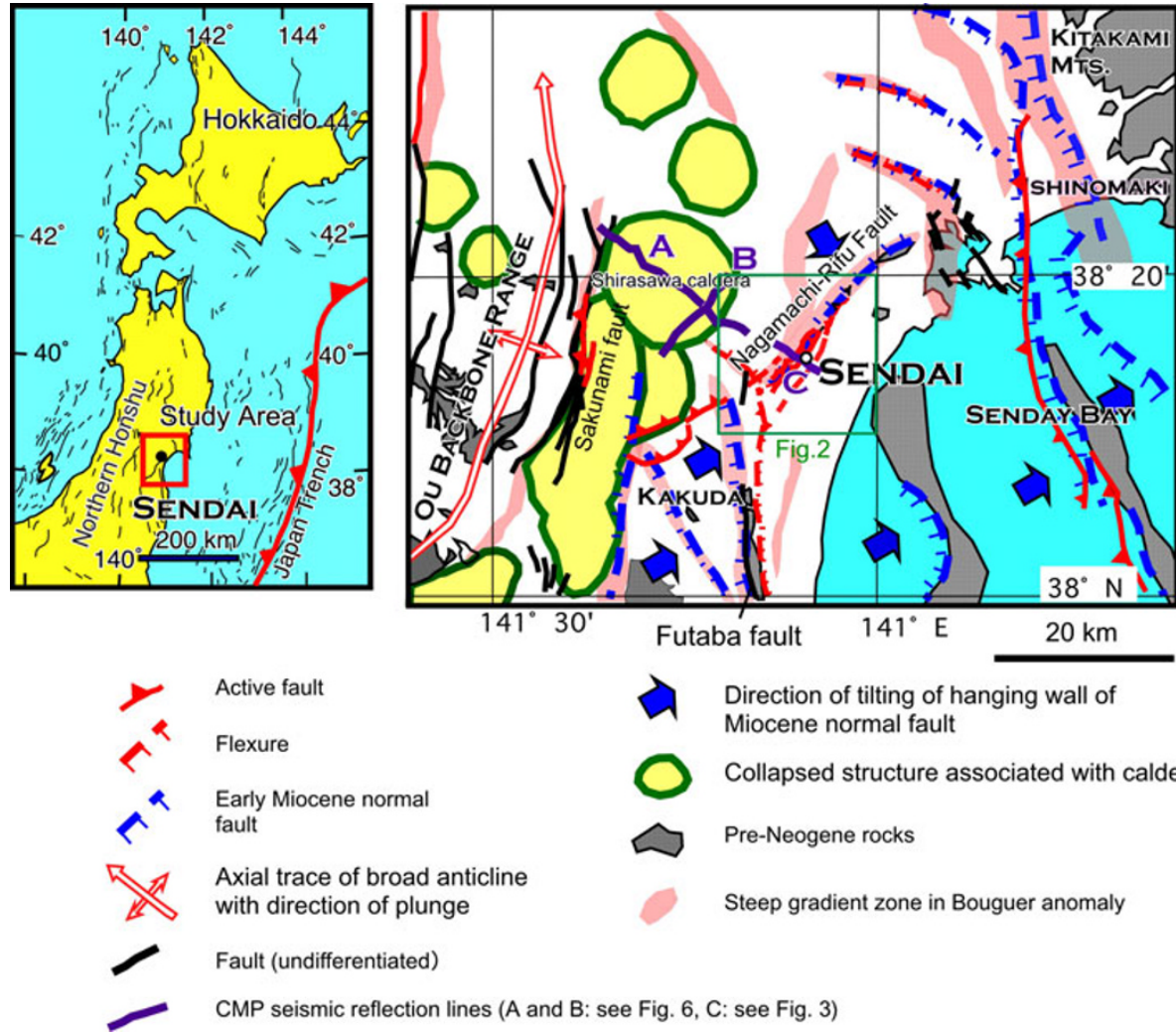

Active fault

Flexure

Early Miocene normal fault

Axial trace of broad anticline with direction of plunge

Fault (undifferentiated)

CMP seismic reflection lines (A and B: see Fig. 6, C: see Fig. 3)

Fig. 1. Geologic structure around Sendai, NE Japan.

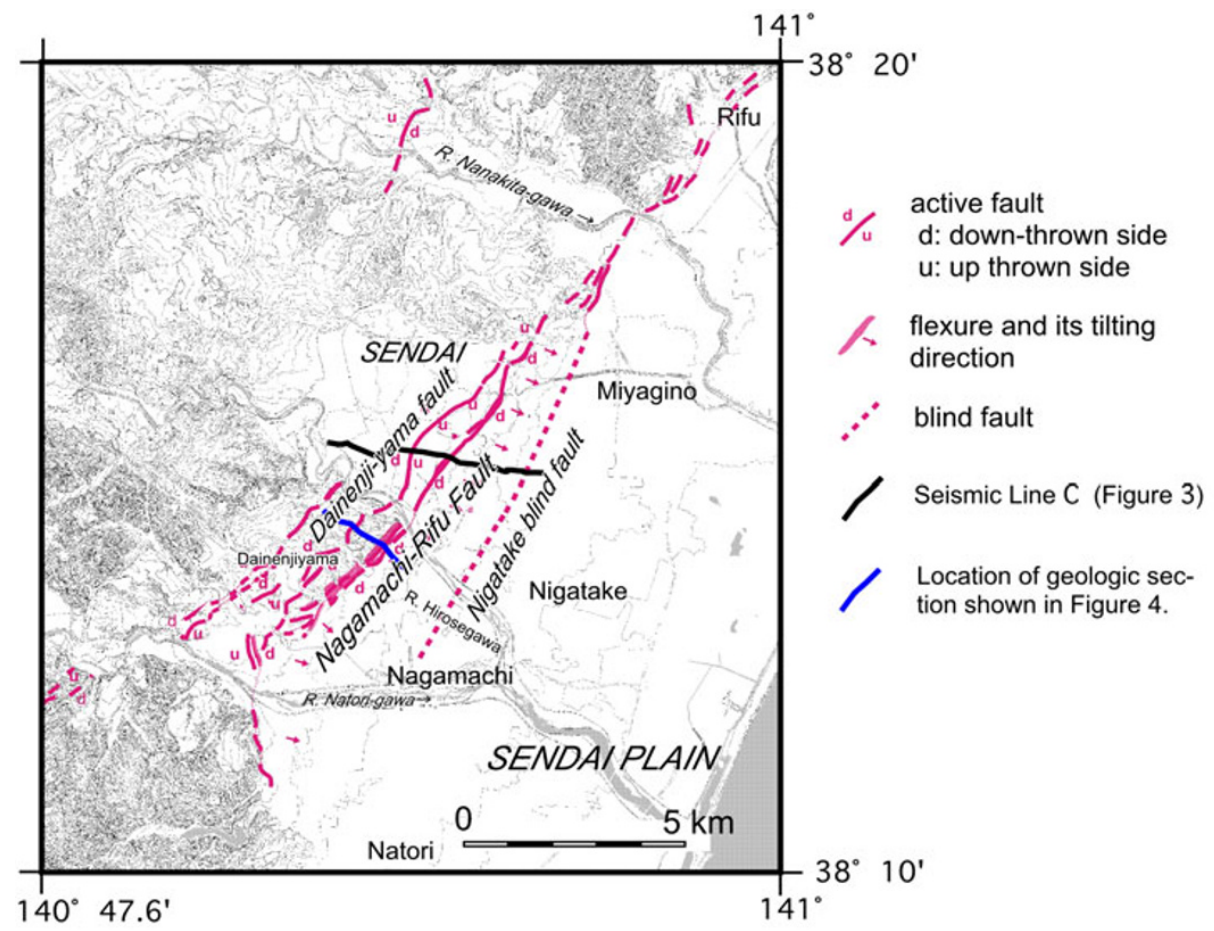

Fig. 2. Active fault map around Sendai City after Imaizumi et al. (2002). Contours of topographic map is $10 \mathrm{~m}$. The area of this figure is shown in Fig. 1.

Recent research on the Nagamachi-Rifu fault revealed subsurface geologic structure of the footwall by drilling (Fig. 4; Miyagi Prefectural Government, 2000). According to the results, the averaged vertical slip rate of the main Nagamachi-
Rifu fault is about $0.7 \mathrm{~mm} / \mathrm{year}$ and the value of the Dainenjiyama fault is $0.1 \mathrm{~mm} /$ year (Fig. 5). As this fault forms a fault system, the vertical slip rate of the master fault reaches nearly one $\mathrm{mm} / \mathrm{year}$. The total amount of horizontal short- 


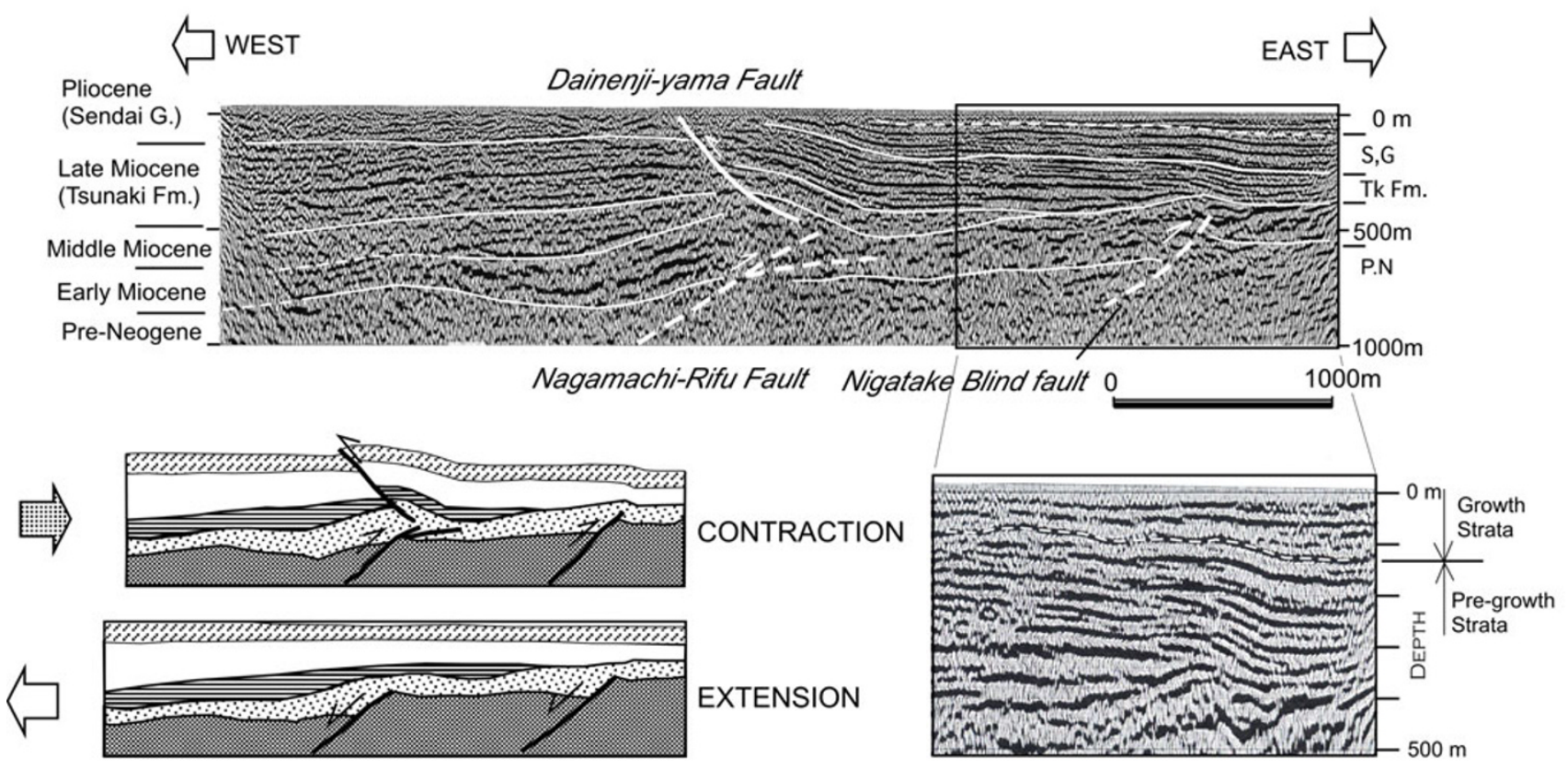

Fig. 3. Seismic reflection profiles across the toe of the Nagamachi-Rifu active fault system (Miyagi Prefectural Government, 1997) and its geologic interpretation. The location of the seismic section is shown in Figs. 1 and 2.

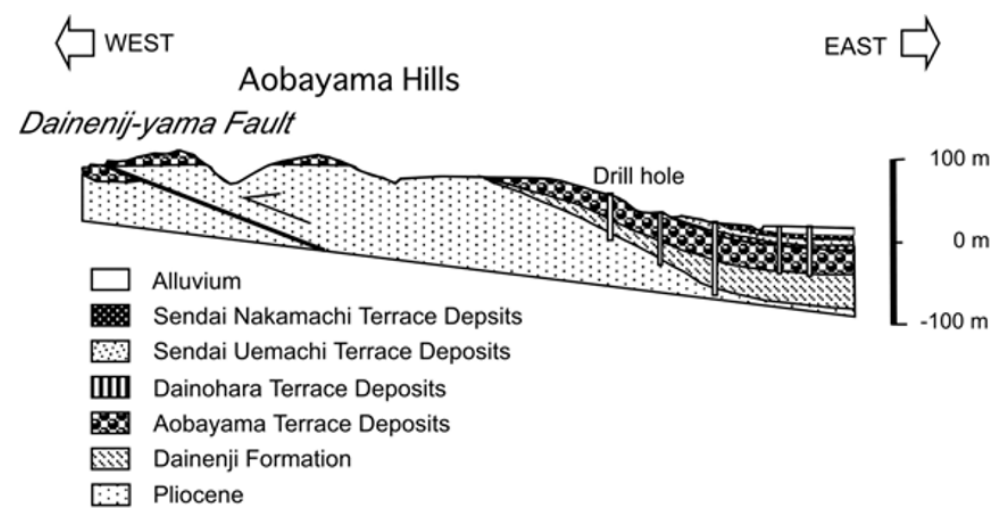

Fig. 4. Shallow geologic structure across the Nagamachi-Rifu fault after Miyagi Prefectural Government (1997). The location of the geologic section is shown in Fig. 2.

ening is about $250 \mathrm{~m}$. Based on the liquefaction features observed in drill cores near Nagamachi-Rifu fault, two possible paleo-seismic events produced by this fault were estimated at 4,500-5,000 y.B.P and 2,500-2,800 y.B.P (Miyagi Prefectural Government, 2000).

\section{Fault Reactivation}

Figure 3 shows the migrated and depth converted seismic reflection profile across the Nagamachi-Rifu fault (Miyagi Prefectural Government, 1997). The Nagamachi-Rifu fault forms a flexure near the surface and does not appear on the surface. Alternatively, the east-dipping Dainenji-yama fault occurs as a back-thrust (Fig. 4). The uplift of the Aobayama Hills is attained by wedge-thrusting of the subsurface westdipping Nagamachi-Rifu fault and the Dainenji-yama fault (emergent back-thrust). Above the Nigatake blind fault, systematic change of the sediment's thickness occurred showing growth strata in the latest Pliocene to Quaternary sediments.

The other outstanding feature in the seismic profile is the change in thickness of the Tertiary sediments between the Nagamachi-Rifu and Nigatake faults. On the hanging wall the thickness of sediments is thicker than on the footwall. This feature clearly demonstrates that the fault was reactivated from normal faulting in Miocene to reverse faulting since late Pliocene. In the northeastern part of the Nagamachi-Rifu fault, lower Miocene thrusted onto preNeogene rocks (Kitamura et al., 1986). The value of the Bouguer anomaly decreases toward the hanging wall, suggesting a thicker sediment cover in the hanging wall than in the footwall (Hiroshima et al., 1991). Fault reactivation from Miocene normal faulting to later reverse faulting was already reported for the eastern part of the Sea of Japan (Okamura et al., 1995) and also in the Sendai Bay area (Nakamura, 1992). 


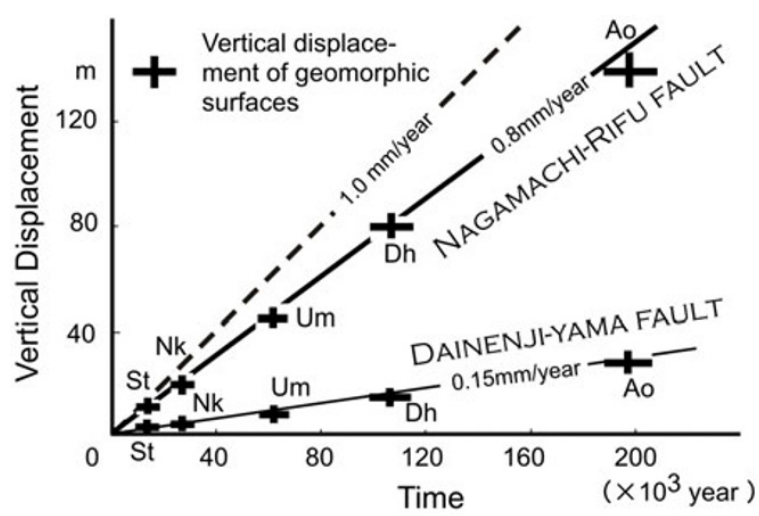

Ao: Aobayama Formation, Dh: Dainohara Terrace, Um: Uemachi Terrace, Nk: Nakamachi Terrace, St: Shitamachi Terrace

Fig. 5. The averaged vertical slip rate of the Nagamachi-Rifu active fault system, deduced by the vertical displacement of river terraces (after Miyagi Prefecture, 1997). The error in observed vertical displacement and age of topographic surfaces are marked by the length of bar.

\section{The Deep Geometry of the Nagamachi-Rifu Fault}

Deep CMP (common midpoint) seismic reflection profiling was carried out in western Sendai to reveal the deep geometry of the Nagamachi-Rifu fault (Ikawa et al., 2001). On the CMP-reflection profile of seismic Line A (Fig. 6), there are some west-dipping reflectors near the hypocenter area of $1998 \mathrm{Mj} 5.0$ Sendai earthquake. The fault plane determined by the focal mechanisms and hypocentral distribution shows dip to the northwest at an angle of 30 degrees (Umino et al., 1999; Okada et al., 2001). The gently west-dipping reflectors at the depth of $12-13 \mathrm{~km}$ on the western half of seismic line A is interpreted as the probable deeper extension of the Nagamachi-Rifu fault (Fig. 6). The geometry of the Nagamachi-Rifu fault shows almost constant dip angle (45 degrees) in the upper crust and decreases its angle to 30 degrees near the bottom of seismogenic layer.

In the upper crust of the eastern-half of line A, many westdipping reflectors are dominant. On the contrary, in the western part of line $\mathrm{A}$ the upper crust is marked by sub-horizontal

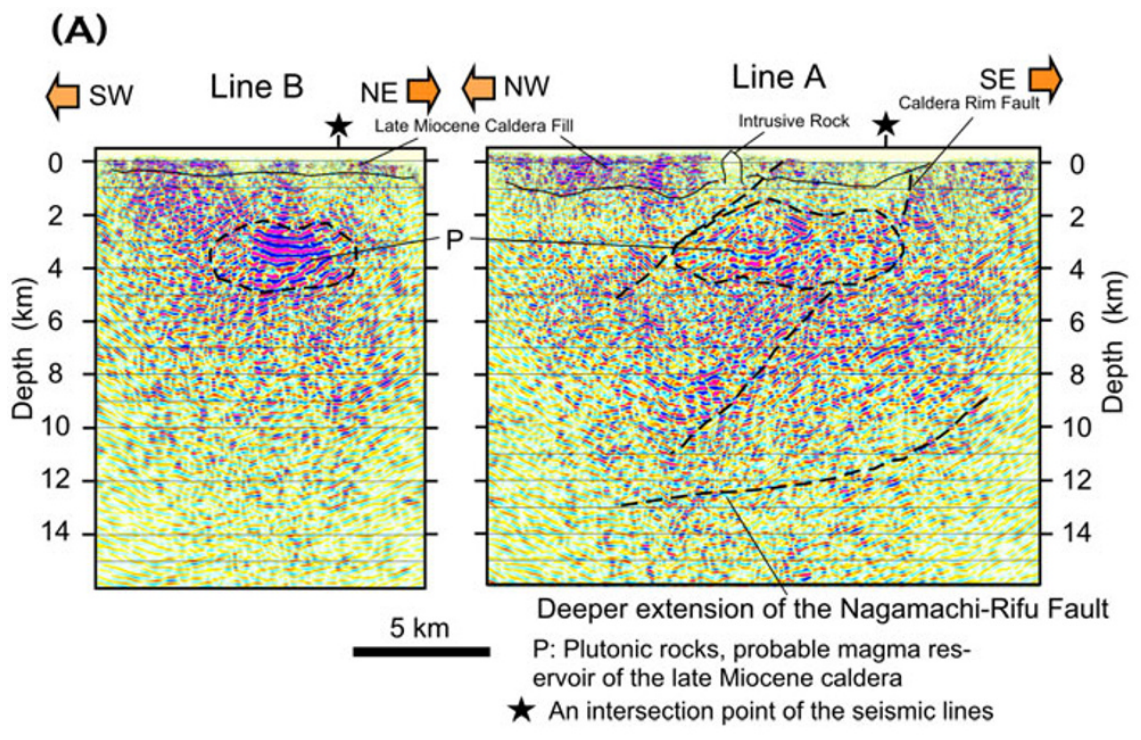

(B)
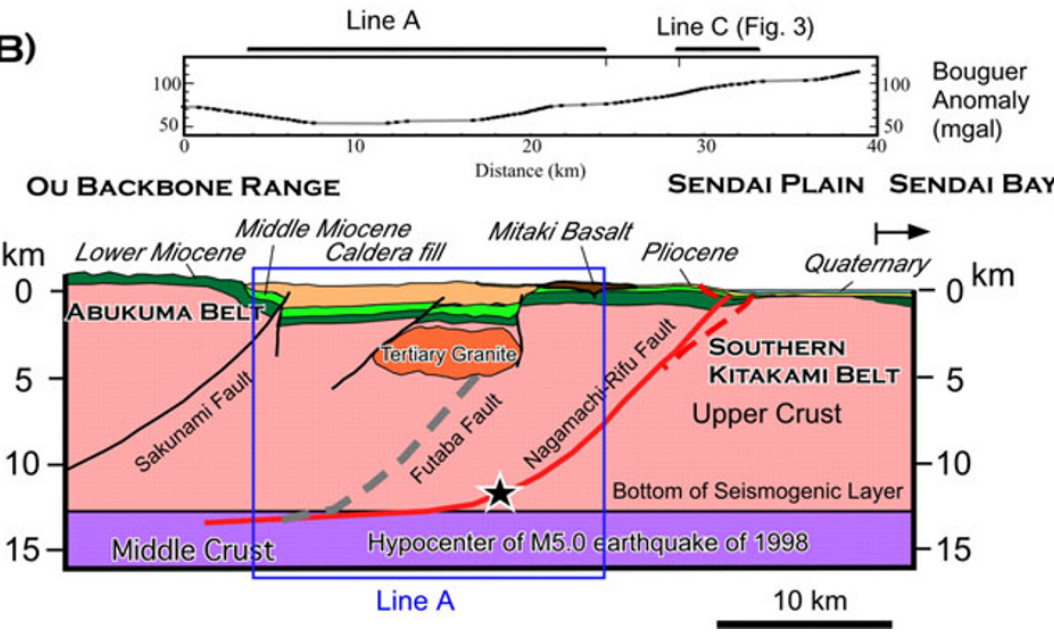

Fig. 6. Deep geometry of the Nagamachi-Rifu active fault systems. (A) Geologic interpretation of deep CMP reflection profiles after Ito et al. (2002). The location of the seismic lines are shown in Fig. 1. (B) Schematic diagram showing the deep geometry of the Nagamachi-Rifu active fault system. The Bouguer anomaly along the seismic line is obtained from the contour map after Hiroshima et al. (1991). 
reflectors. This change in dip angle of reflectors occurs at the direct extension of the Futaba fault, which is a Cretaceous to Paleogene strike-slip fault that has large displacement. In the Kakuda basin, south of Sendai (Fig. 1), the early Miocene graben was formed along the Futaba fault. Judging from the west-dipping normal faulting in the early Miocene, the northwestern extension of the Futaba fault is interpreted as a west-dipping fault (Fig. 6). The boundary between the above-mentioned west-dipping and sub-horizontal reflection domains in the upper crust is traced by a west-dipping line in Fig. 6, suggesting the extension of the Futaba fault.

The area marked by lower frequency reflections (ca. 12 $\mathrm{Hz}$ ) is identified in the central part of both seismic lines at the depth of $2-5 \mathrm{~km}$ in a region of $8 \mathrm{~km}$ diameter. As its special distribution is restricted within the Shirasawa caldera, we interpreted it as plutonic rocks which were formed in the late Miocene as a source reservoir of this felsic caldera. The low frequency reflections are associated with the top of the reservoir and its upper most internal structures. The shallow part $(<1 \mathrm{~km})$ above the possible plutonic rocks shows coherent reflectors and is interpreted as caldera fill (Fig. 6).

\section{Conclusions}

The Nagamachi-Rifu fault is a west-dipping reverse fault and splays in the uppermost crust forming a fault system with the Dainenji-yama fault and Nigatake blind fault. The master portion of the Nagamachi-Rifu active fault system shows the net slip rate of one $\mathrm{mm} /$ year. Judging from the shallow seismic reflection profile, surface geology and gravity anomaly, the fault system was originally formed as a normal fault in early Miocene and subsequently reactivated as a reverse fault. Based on the deep CMP seismic reflection profiles (Ikawa et al., 2001) and seismic activity (Umino et al., 1999), the deeper extension of the Nagamachi-Rifu fault shows moderate dip angle (45 degrees) in the upper crust and decreases its angle to 30 degrees near the bottom of seismogenic layer.

Acknowledgments. We are grateful to Takaya Iwasaki, Takeshi Ikawa and David Okaya for helpful discussions. We also thank to Ono Onken, Koichiro Fujimoto and Yasuo Ogawa for reviewing the manuscript.

\section{References}

Amano, K., Geology of the Ou Backbone Ranges in Miyagi and Yamagata Prefectures, Northeast Honshu Japan, Contrib. Inst. Geol. Paleontol. Tohoku Univ., 81, 1-56, 1980 (in Japanese with English abstract).
Hasegawa, A., N. Umino, and S. Hori, Seismic activity and inhomogeneous structure of the crust around the Nagamachi-Rifu fault, Earth Monthly, 23, 313-320, 2001 (in Japanese).

Hiroshima, T., M. Komazawa, M. Okuma, T. Nakatsuka, M. Mishina, and K. Okamoto, Gravity (Bouger) anomaly map of Yamagata district, Gravity Map Series 3, 1:200,000, Geological Survey of Japan, 1991.

Ikawa, T., T. Kawanaka, S. Kawasaki, A. Hasegawa, N. Umino, A. Nakamura, H. Ito, T. Iwasaki, and H. Sato, Seismic reflection survey of the deep structure of Nagamachi-Rifu fault, Northeast Japan, Proceedings of the International Symposium on Slip and Flow processes in and below the Seismogenic Region, Sendai, Japan, pp. 301-308, 2001.

Imaizumi, T., S. Sawa, H. Sato, S. Hirano, M. Watanabe, and H. Yagi, Active fault system in Sendai and Fukushima area, in Atlas of Quaternary Thrust Faults in Japan, edited by Y. Ikeda et al., pp. 100-111, Univ. of Tokyo Press, Tokyo, 2002.

Kitamura, N. (Ed.), Cenozoic Arc Terrane of Northeast Honshu, Japan, 3 vols., Hobundo, Sendai, Japan, 1986 (in Japanese).

Kitamura, N., T. Ishii, A. Sangawa, and H. Nakagawa, Geology of the Sendai district, with Geological Sheet Map at 1:50,000, Geol. Surv. Japan, 134 pp., 1986 (in Japanese with English abstract).

Miyagi Prefectural Government, Research on the Nagamachi-Rifu fault, Abstract for the Results of active fault research supported by Headquarters for Earthquake Research Promotion, No. 1. The Science and Technology Agency, Japan, 30-34, 1997 (in Japanese).

Miyagi Prefectural Government, Research on the Nagamachi-Rifu fault, Abstract for the Results of active fault research supported by Headquarters for Earthquake Research Promotion, No. 2. The Science and Technology Agency, Japan, 29-34, 2000 (in Japanese).

Nakamura, K., Inversion tectonics and its structural expression, J. Tectonic Res. Group Japan., 38, 3-45, 1992 (in Japanese with English abstract).

Nakata, T., K. Otsuki, and T. Imaizumi, Quaternary crustal movement along the Nagamachi-Rifu dislocation line in the vicinity of Sendai, northeast Japan, Annals. Tohoku Geographical Association, 28, 111-120, 1976 (in Japanese with English abstract).

Okada, T., N. Umino, T. Matsuzawa, A. Hasegawa, and M. Kamiyama, Source processes of 15 September 1998 M 5.0 Sendai, northeastern Japan, earthquake and its M 3.8 foreshock by waveform inversion, Bull. Seismol. Soc. Am., 91, 1607-1618, 2001.

Okamura, Y., M. Watanabe, E. Morijiri, and M. Satoh, Rifting and basin inversion in the eastern margin of the Japan Sea, Island Arc, 4, 166-181, 1995.

Otsuki, K., T. Nakata, and T. Imaizumi, Quaternary crustal movements and block model in the southeastern region of the northeast Japan, Earth Science (Chikyu-Kagaku), 31, 1-14, 1977 (in Japanese with English abstract).

Sato, H., The relationship between late Cenozoic tectonic events and stress field and basin development in northeast Japan, J. Geophys. Res., 99, 22261-22274, 1994.

Umino, N., T. Okada, T. Matsuzawa, S. Hori, T. Kono, K. Nida, A. Hasegawa, and N. Nishide, On M5.0 earthquake that occurred at the deepest portion of Nagamachi-Rifu fault on September 15, 1998, Earth Monthly, special issue, 27, 148-154, 1999 (in Japanese).

Yoshida, T., The evolution of arc magmatism in the NE Honshu arc, Japan, Tohoku Geophysical Journal, 36, 131-149, 2001.

H. Sato (e-mail: satow@eri.u-tokyo.ac.jp), T. Imaizumi, T. Yoshida, H. Ito, and A. Hasegawa 